\title{
Management Information System of the Billing Subsystem: A Prototype Design
}

\author{
Farida Setianingsih ${ }^{1}$, Adhistya Erna Permanasari ${ }^{2}$, Warsun Najib ${ }^{3}$
}

\begin{abstract}
Prof. Soeparwi Veterinary Hospital is one of veterinary medical service providers in Yogyakarta ad Central Java areas in which the transaction and the documentation managing process is still done manually. Therefore, Prof. Soeparwi VH needs a management information system that facilitate them in managing process and documentation of transactions, one of which is through billing or billing subsystem. This subsystem was designed using UML and was developed in a form of web-based prototype using PHP and HTML languages as well as CSS with CodeIgniter framework and MySQL for database. The development of this billing subsystem applied a Rapid Application Development (RAD) model process that focused on the working model and obtained feedback from users to improve the system. Results of this system's development were evaluated with a system feasibility test and functionality test. A system feasibility test was administered by distributing Likert scale questionnaire and analysed them based on a summated rating scale method which showed a result of $85.4 \%$. That result indicates that users strongly agree that the system has met their needs. The system functionality was tested using a black box method and the result was that the system properly functioned. This billing subsystem could process transaction bills automatically included in the calculation. This system produced bills and reports that could be printed and exported. In addition, data was stored in a database so that it supported paperless documentation.
\end{abstract}

Keywords - Billing, Transactions, Documentation, Prototypes, Management Information Systems.

\section{INTRODUCTION}

Prof. Soeparwi Veterinary Hospital (VH) is one of two veterinary hospitals in Yogyakarta and Central Java areas. This $\mathrm{VH}$ is one of veterinary medical service providers [1]. The overall service courses of Prof. Soeparwi VH applied in patients handling today is relatively complex [2]. Service courses in $\mathrm{VH}$ includes registration, medical records, pharmacies, billing, and cashiers. Most of either transactions or activities in VH are still recorded manually. Transaction documentation is administered manually using Microsoft Excel which later must be inputted manually.

From that problem, the VH requires an information system regulating financial transactions of services through a billing

\footnotetext{
${ }^{1}$ Department of Electrical Engineering and Information Technology of Universitas Gadjah Mada, Jln. Grafika 2, Kampus UGM Yogyakarta 55281 INDONESIA (telp: 0274-552305; fax: 0274-552305; e-mail: farida.setianingsih@mail.ugm.ac.id)

2,3 Lecturers, Department of Electrical Engineering and Information Technology, Faculty of Engineering, Universitas Gadjah Mada, Jln. Grafika 2, Kampus UGM Yogyakarta 55281 INDONESIA (telp: 0274-552305; adhistya@ugm.ac.id; warsun@ugm.ac.id)
}

system. This billing system was developed to provide convenience in digitalizing bills from patients to $\mathrm{VH}$ according to services provided to the animals. This billing system was expected to be able to facilitate $\mathrm{VH}$ in processing and documenting transactions to make decisions.

\section{MANAGEMENT INFORMATION SYSTEM IN VETERINARY HOSPITAL}

An information system can be said as a link between components that take, process, store and distribute information to assist in decision making, coordination, control and management facilitated with information technology [3]. Development of information systems that support users that are needed specifically from the technical side can use the Unified Modelling Language (UML) [4]. In the last few years the constructed information systems have been integrated with the internet and business transaction processes. Many health clinics and hospitals are trying to have digital information systems to keep patient health records, billing, and health insurance claims processes [5]. Information systems applied in business process in the health sectors, i.e. hospitals or health services, are carried out by applying information technology to improve effectiveness of billing interfaces in bookkeeping and to improve financial statements from the transaction results. This is done because paper-based billing operations are more prone to errors when entering data and additional time is needed to manage billing regarding payments or reimbursements. Application of information technology in billing operations helps health personnel in verifying patients' data from progress records and helps improving access to information and reduce errors when entering database [6].

Service providers in health sectors have realized the importance of digitalizing patients health records through various information systems, generally in a form of a management information system [5], [7], because entering billing data into documentation can save clinic staffs' time in determining patients' total cost and allow improvement of bookkeeping and billing system [8].

\section{A. Veterinary Hospital}

$\mathrm{VH}$ is one of veterinary medical service providers for therapeutic transaction practice category. Therapeutic transaction is a veterinary medical service involving veterinarians, clients and patient in return for services and facilities used. Other actions carried out by veterinary medical personnel include prognosis, diagnosis, examination and testing, referral, disease data and activities delivery to the authorities, following up on Government decree related to disease and veterinary health, as well as conducting client education on health paradigms and animal welfare [1]. 


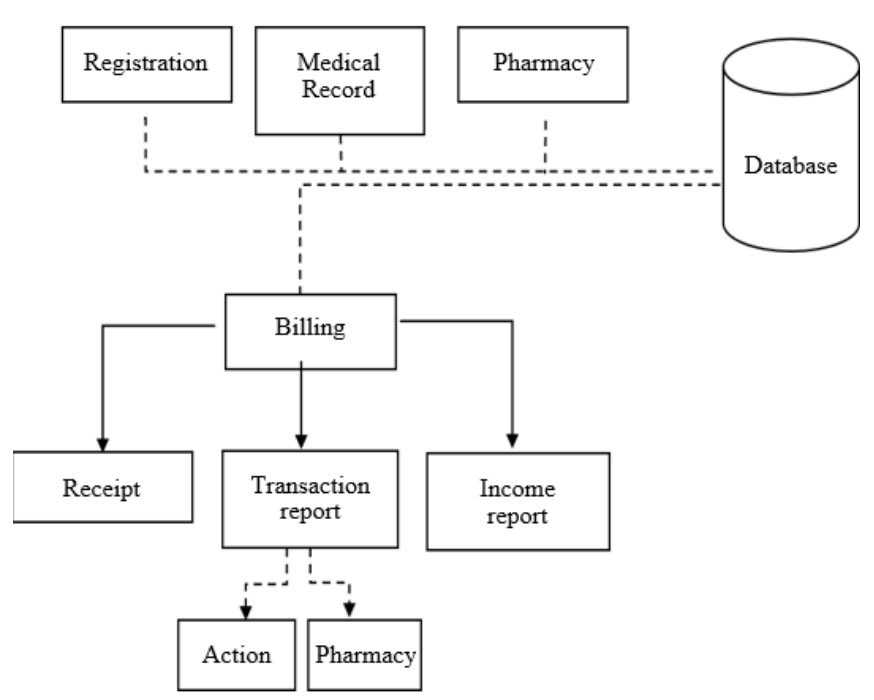

Fig. 1 Conceptual model of business processes.

\section{B. Management Information System}

An information system developed in an agency or organization and build as needed, either a system to process transactions, Management Information System (MIS) or decision support systems [9]. MIS is a system that processes data into outputs used by management to analyse problems, in decisions making, and the next steps [10], [11].

\section{Billing System}

This system is related to software and hardware that receive requests and special information services based on information from used. It creates management report and prints payments for user formed from interfaces, computers, software program, and information databases [12]. Its functions include creating usage records, handling processes, calculating total costs, payment processes, and management reporting [12], [13].

\section{Database}

Database is a collection of interrelated and organized information. All data are described and collected with other data. For unrelated data, a separate database is provided [14].

\section{E. Unified Modelling Language (UML)}

UML is an image notation used as a visual language to explain, describe, construct, and document the components needed in a software system and business model [15], [16].

\section{METHODS}

This paper was developed with reference to a conceptual model of business process in Fig. 1 by implementing Rapid Application Development (RAD) model process in Fig. 2. RAD was used because it was a system development method focused on the work model and obtained feedback from users to improve the model.

\section{A. Requirement Planning}

To get the things needed, literature studies and interviews with Prof. Soeparwi VH was carried out to find out comprehensive needs. According to the Prof. Soeparwi VH, the required system could help them in financial calculations such as payments as well as transaction documentation.

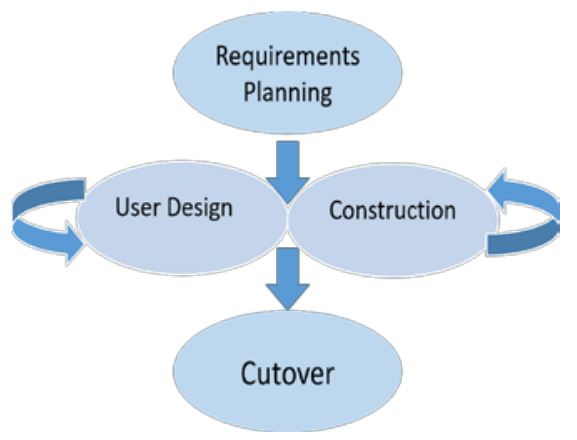

Fig. 2 Steps of RAD model process [14].

\section{B. User Design}

User as a stakeholder was involved in creating this system design in discussing the design of information system. This information collection section is often referred to as a joint application development [14].

1) System Design: The System design was carried out using UML diagrams based on conceptual model of billing subsystem business processes. System design with use case diagram is shown in Fig. 3.

This use case diagram displays system interaction with actor to describe static aspects of the system. Actors are internal or external factors that produce interactions. In this system, the actors were admin and staff. Then an action scenario was developed from the use case to become an activity diagram and sequence.

2) Menu Design: The billing subsystem menu was divided into five, namely Home, Master Data, Cost Data, Transactions, and Reports.

3) Interface Design: The interface design was carried out with a wireframe model. The example design interface with wireframe for the Home page is shown in Fig. 4.

From wireframe in Fig. 4 interfaces structures for other menus are more or less the same

4) Database Design: In this section, a table was designed to be used for system development with Entity-Relationship diagrams as in Fig. 5.

\section{Construction}

The HTML, CSS, and PHP were used in this web-based system development. MySQL was used in the database development. This system programming was carried out using CodeIgniter framework with interface from Bootstrap framework.

\section{Cutover}

System was tested by users and it was evaluated according to user's feedback to improve the system. Reiteration of this step was carried out by analysing the design and building the system repeatedly until the system was in accordance with the user needs. 


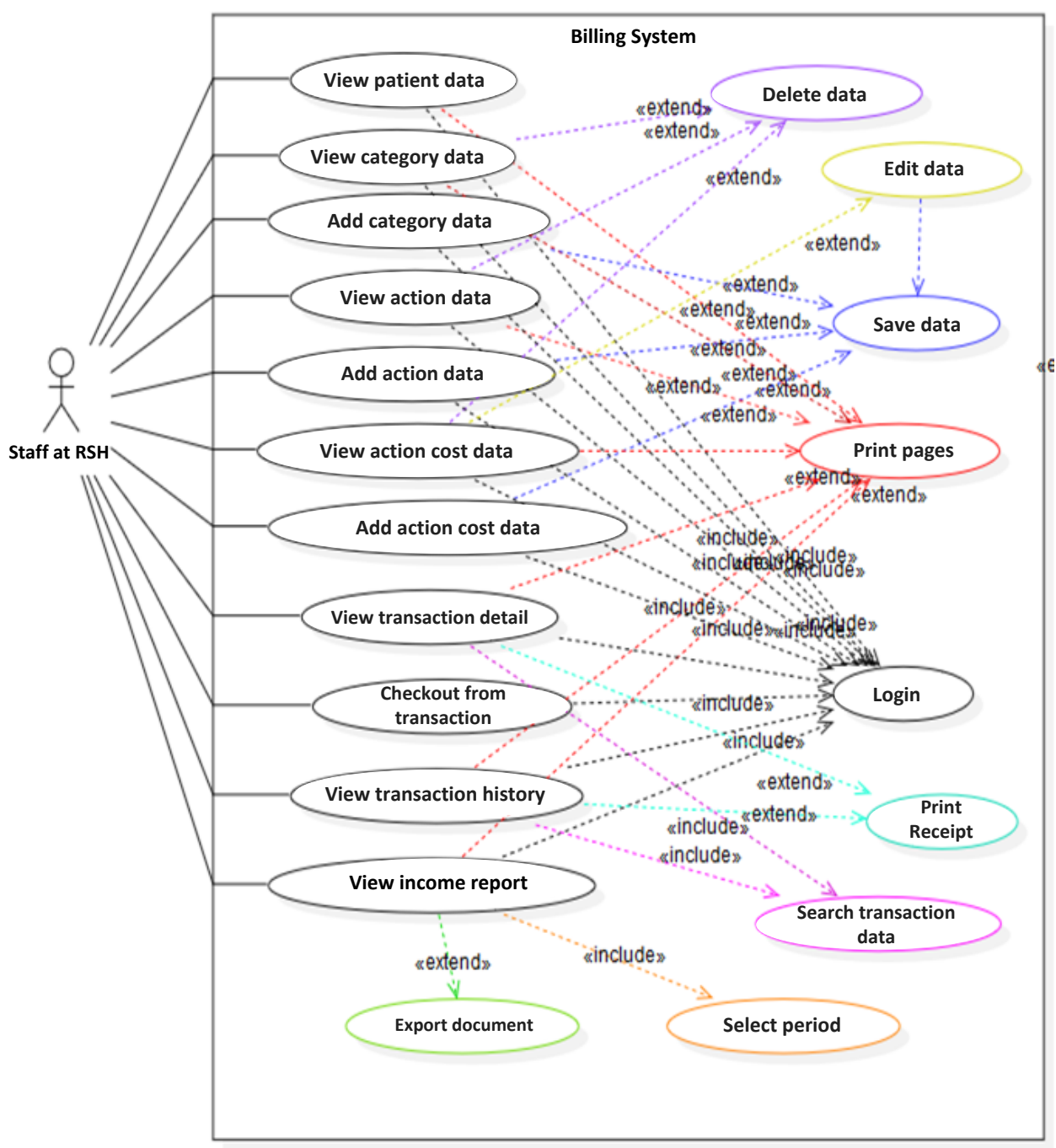

Fig. 3 Use case diagram of billing subsystem.

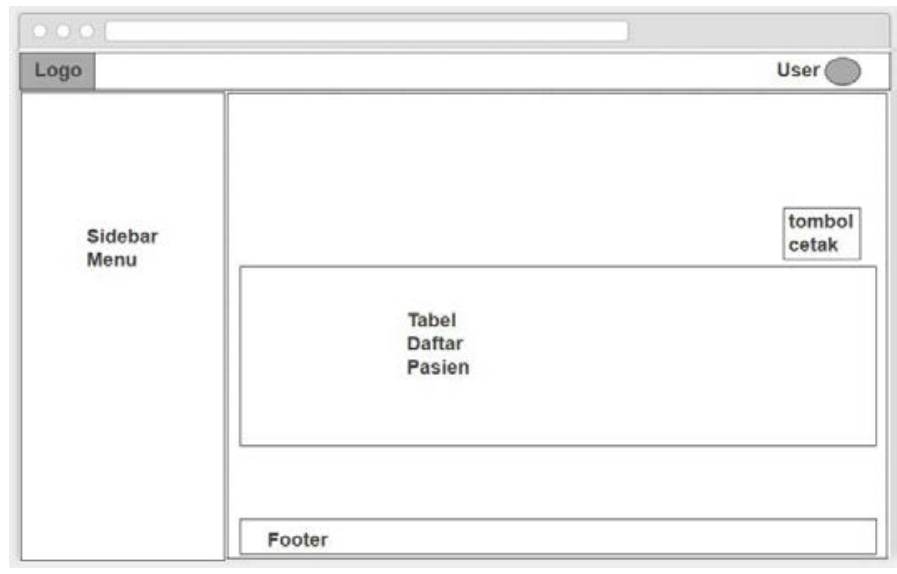

Fig. 4 Interface design of Home page.

In this stage, a test was carried out with a system feasibility test scenario and system functionality test. A black box test was carried out by testing the input as well as output data to find out problems in the system's functions or features. Meanwhile, a system feasibility test was carried out by distributing questionnaires to users containing statements and assessed with a Likert scale. The results were calculated by rating scale analysis according to data in Table I.

TABLE I

Percentage of Rating Scale Analysis Assessment

\begin{tabular}{|c|c|c|}
\hline Assessment Percentage & Scale & Description \\
\hline $0 \%-19.99 \%$ & 1 & Strongly Disagree \\
\hline $20 \%-39.99 \%$ & 2 & Disagree \\
\hline $40 \%-59.99 \%$ & 3 & Fairly agree/Neutral \\
\hline $60 \%-79.99 \%$ & 4 & Agree \\
\hline $80 \%-100 \%$ & 5 & Strongly disagree \\
\hline
\end{tabular}

\section{REsUlts AND Discussions}

\section{A. Development Results}

This billing subsystem development was still in a prototype stage used for processing data and transactions, then issued them in a form of documentation such as bills and reports that 


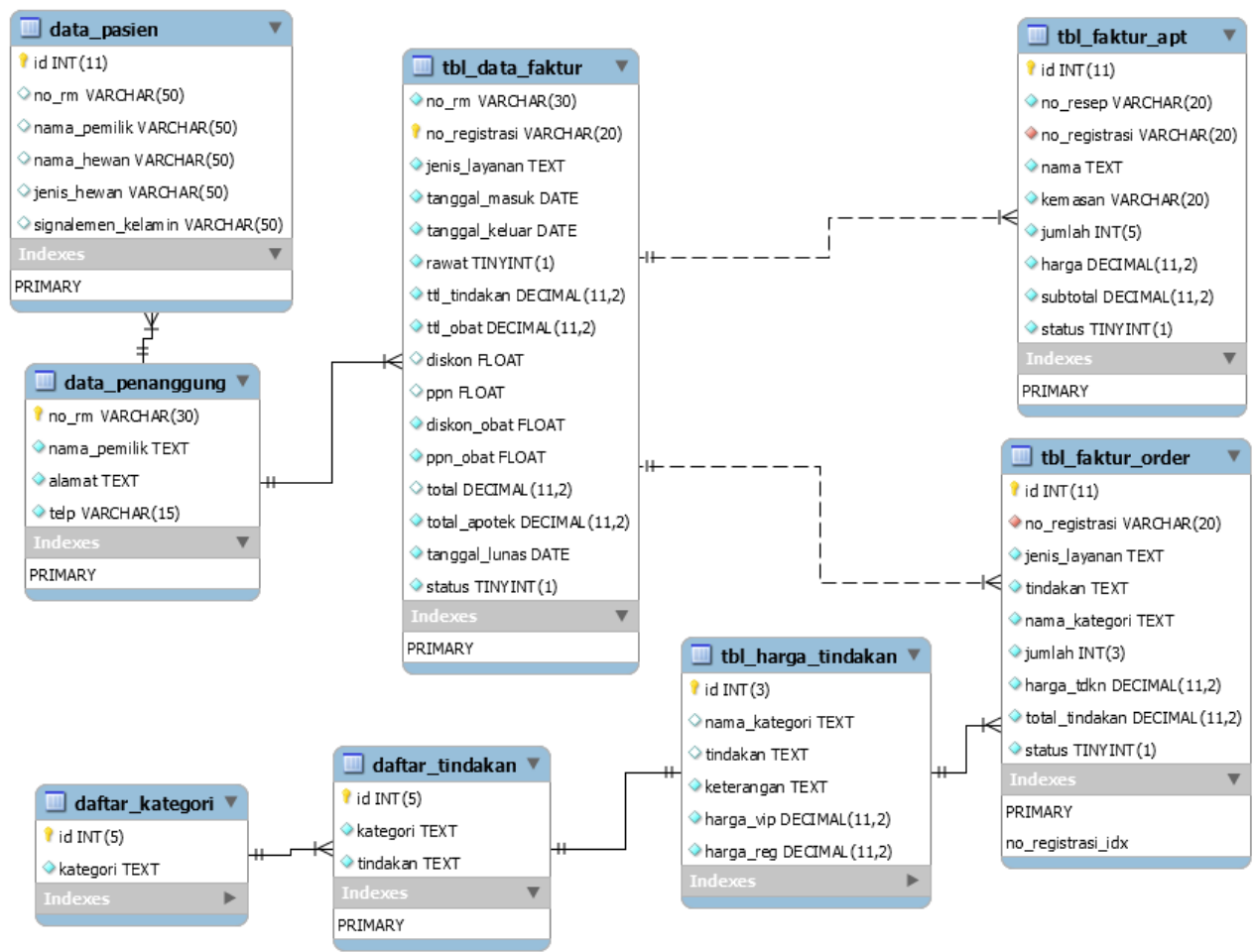

Fig. 5 Database design and its connection.

Daftar Tagihan : Open

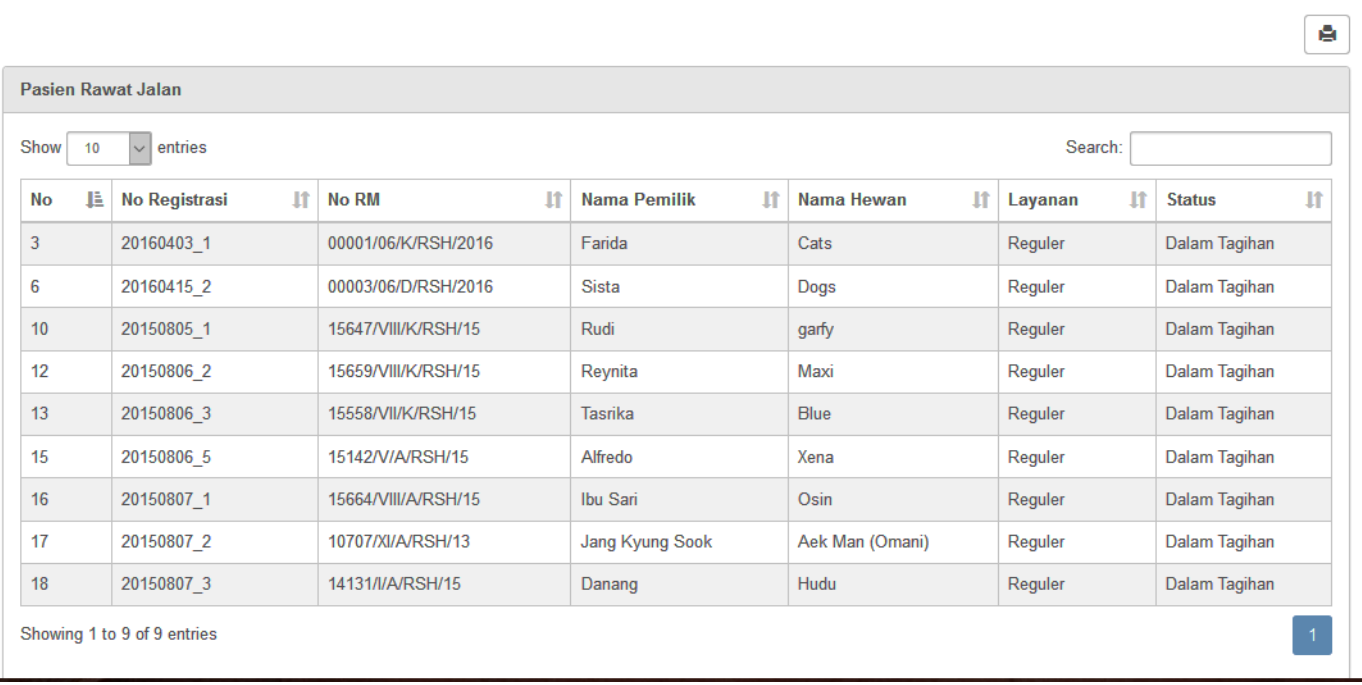

Fig. 6 Home page.

could still be used for the next process. Transactions was carried out according to the patient's registration number obtained at the beginning of registration. Every new transaction of a same patient was added into unpaid registration number bill or in an open status or to new registration number. Results of this prototype development are shown in Fig. 6 to Fig. 10.

Fig. 6 shows a Home page and Fig. 7 shows a Cost Data page. The Home page displays patient's data or list of unpaid bills, while Fig. 7 displays VIP and Regular process of actions or services performed at $\mathrm{VH}$.
Fig. 8 is a page on a Transaction menu. This page is in a form of blank note format that will be filled after the data has been searched. Fig. 9 and Fig. 10 are pages on report menu, i.e. Transaction History page and Receipt Report page.

\section{B. Evaluation}

Evaluation results of system feasibility test in Table II shows that users strongly agree that system has met the requirements referenced from the assessment percentage in Table II. While the functional test results show that the system is running well. 


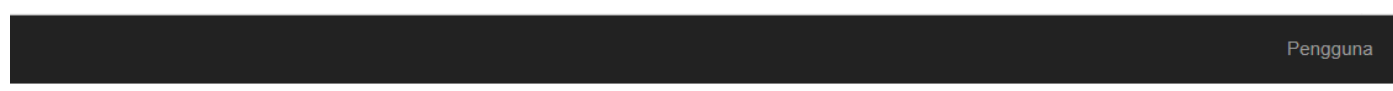

\section{Daftar Harga Tindakan}

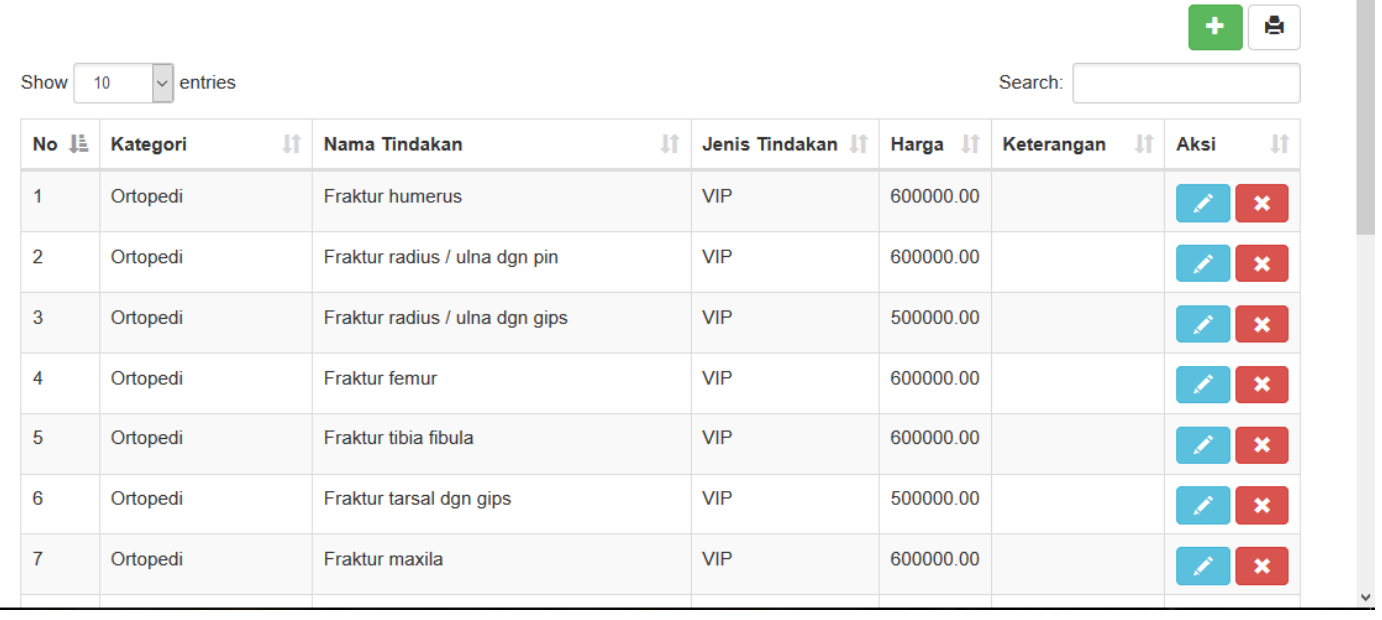

Fig. 7 Cost Data page.

Transaksi Tindakan

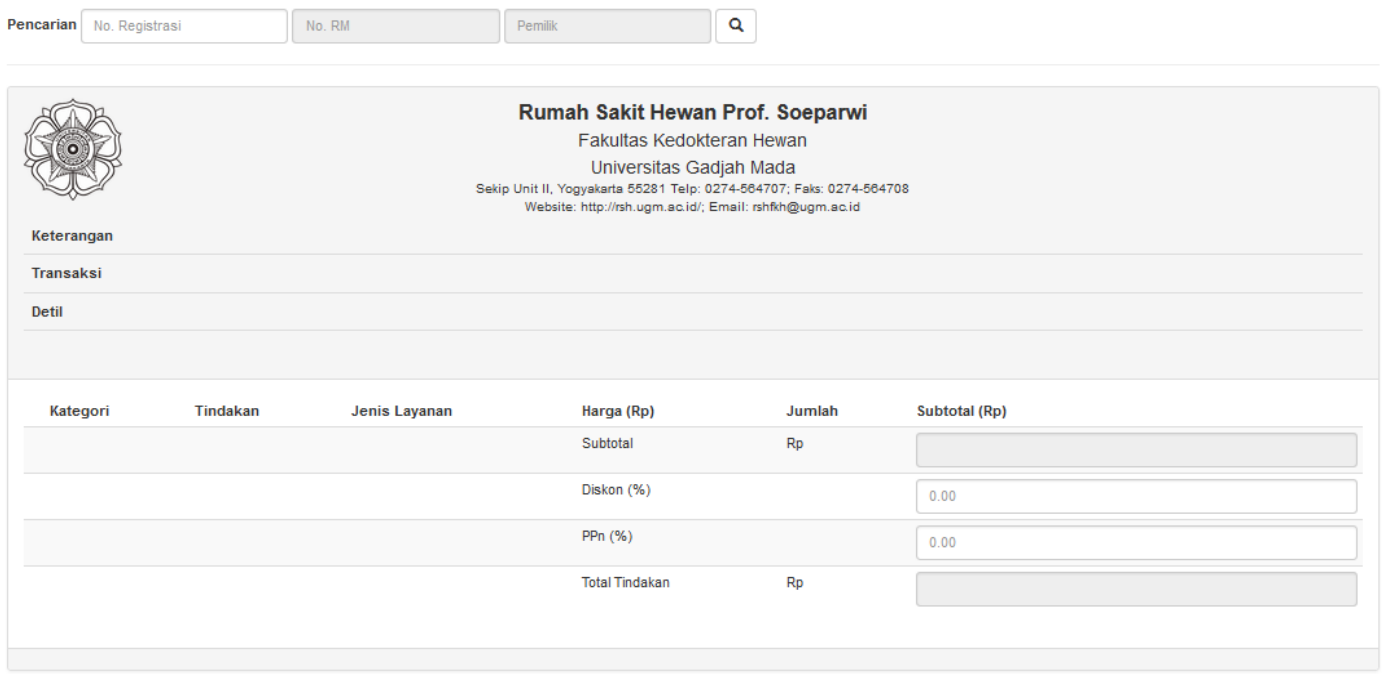

Fig. 8 Transaction page.

TABLE II

TABLE OF SYSTEM FEASIBILITY TEST RESULTS

\begin{tabular}{|l|r|r|}
\hline \multicolumn{1}{|c|}{ Results } & \multicolumn{1}{c|}{ User 1 } & \multicolumn{1}{c|}{ User 2 } \\
\hline Total score & 106 & 82 \\
\hline f/(the highest scale*question) & 0.9636364 & 0.7454545 \\
\hline Percentage & $96.36 \%$ & $74.54 \%$ \\
\hline Average & \multicolumn{2}{|c|}{$85.45 \%$} \\
\hline
\end{tabular}

\section{Strengths and Weaknesses of the System}

Billing subsystem provides convenience for staff to process transactions. Reporting can be done automatically by taking data from database and this billing subsystem also support paperless documentation
However, the billing subsystem is still being developed in a form of a prototype that is run using localhost, so it cannot be accessed online both from inside and outside RSH. Receipt reports can be exported to Microsoft Excel, but only limited to total calculations and reporting statistics have not been built in the development of this subsystem.

\section{CONCLUSION}

From this study, it can be concluded that billing subsystem prototype developed with CodeIgniter framework has facilitated user in processing transactions digitally and automatically. In addition, this system also reduced paper used in documentation because data documentation was done by 


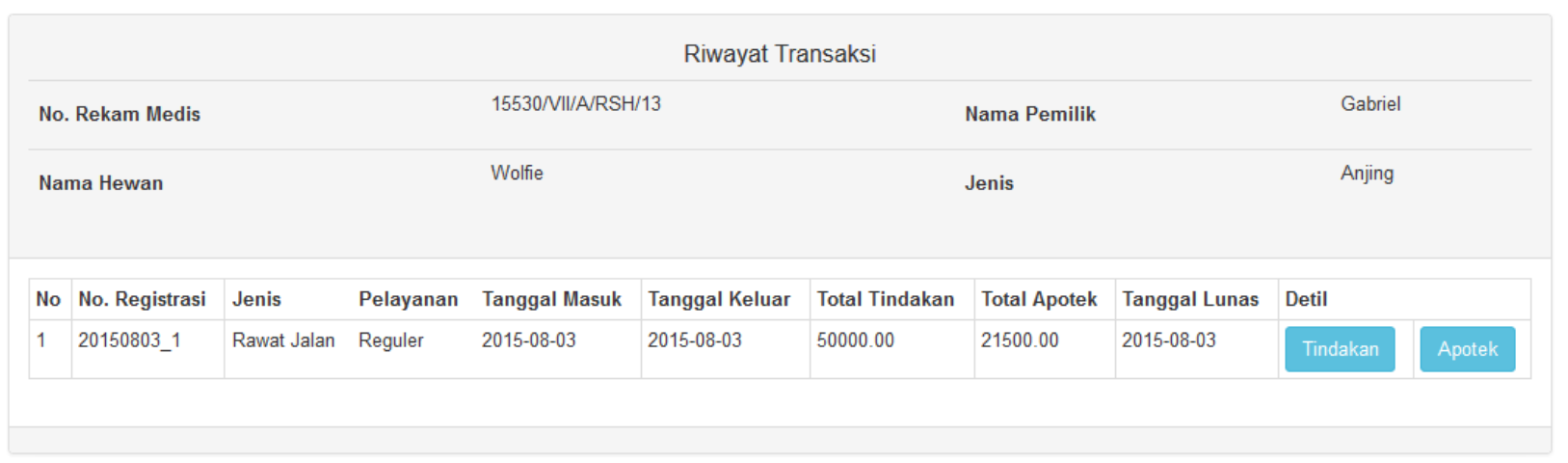

Fig. 9 Transaction History page.

$\begin{array}{lll}\text { Tanggal Awal } & 2015-07-01 \\ \text { Tanggal Selesai } & 2015-09-01 & \text { Q Tampilkan }\end{array}$

Hasil Pencarian

Periode tanggal 2015-07-01 sampai tanggal 2015-09-01

\begin{tabular}{|c|c|c|c|c|c|}
\hline \multicolumn{2}{|c|}{ (2) } & \multicolumn{3}{|c|}{$\begin{array}{c}\text { Rumah Sakit Hewan Prof. Soeparwi } \\
\text { Fakultas Kedokteran Hewan } \\
\text { Universitas Gadjah Mada } \\
\text { Sekip Unit ll, Yogyakarta 55281 Telp: 0274-564707; Faks: 0274-564708 } \\
\text { Website: http:Ilrsh.ugm.ac.dil; Email: rshfkh@ugm.ac.id }\end{array}$} & \multirow[b]{2}{*}{ Total Dibayarkan } \\
\hline No & No. Registrasi & Nama Hewan & Tanggal Lunas & Total Apotek & \\
\hline 1 & 20150801_1 & Posky & 2015-08-01 & 0 & $104,800.00$ \\
\hline 2 & 20150803_1 & Wolfie & 2015-08-03 & 21,500 & $71,500.00$ \\
\hline 3 & 20150806_1 & Keny & 2015-08-06 & 0 & $195,000.00$ \\
\hline \multirow[t]{2}{*}{4} & 20150806_4 & Mola & 2015-08-06 & 0 & $195,000.00$ \\
\hline & & & Total (Rp) & $21,500.00$ & $566,300.00$ \\
\hline
\end{tabular}

Fig. 10 Receipt Report page.

storing it to the database and it also supported report making by retrieving data from database based on period without having to manually reconcile transactions one by one.

\section{REFERENCES}

[1] “Pedoman Pelayanan Jasa Medik Veteriner," Peraturan Menteri Pertanian Republik Indonesia, No. 2, 2010.

[2] (2012) "RSH Prof. Soeparwi,” [Online], http://rsh.fkh.ugm.ac.id, access date: 30-Apr-2016.

[3] K.C. Laudon and J.P. Laudon, Management Information Systems: New Approaches to Organization and Technology, New Jersey, USA: Prentice Hall, 1997.

[4] S.N. Boranbayev, "Methods of Identification of Mathematical Model," The IABPAD Conference Proceedings, 2009, pp. 1228-1231.

[5] A.S. Boranbayev and N.S. Boranbayev, "Development and Optimization of Information Systems for Health Insurance," Seventh International Conference on Information Technology, 2010, pp. 1282-1284.

[6] C.S. Jao, C.M. Helgason, and D.A. Zych, "Implementing a Computerized Charge Capture System to Improve Billing Work Flow and Reduce Errors in Data Entry,” Journal of Computers, Vol. 4, No. 2, pp. 127-134, February 2009.

[7] H. Jogiyanto, Analisa dan Desain Sistem Informasi, Yogyakarta, Indonesia: Penerbit Andi, 2005.
[8] K.A. Jones, “Automated Coding, Billing, and Documentation Support for Endoscopy Procedures,” Thesis, The Ohio State University, Ohio, USA, 2012.

[9] R.L. Alcami and C.D. Caranana, Introduction to Management Information Systems, 1st ed., Castello de la Plana, Spain: Universitat Jaume I, 2012.

[10] M.B. Leba, "Analisis Pemanfaatan Billing System di RSUD Dr. T.C. Hillers Maumere,” Master Thesis, Universitas Gadjah Mada, Yogyakarta, Indonesia, 2014.

[11] L. Zulfa, "Rancangan Billing System pada Pelayanan Instalasi Rawat Inap Rumah Sakit Ibu dan Anak Puspa Husada (2012),” Magister Thesis, Universitas Indonesia, Depok, Indonesia, 2013.

[12] M.S. Al-Ani, R. Noory, and D.Y. Al-Ani, "Billing System Design Based on Internet Environment," International Journal of Advanced Computer Science and Applications, Vol. 3, No. 9, pp. 224-230, 2012.

[13] D.P. Ferenc, Understanding Hospital Billing and Coding, 2nd ed., Philadelphia, USA: Saunders, 2010.

[14] D.T. Bourgeois, Information System for Business and Beyond, Washington DC, USA: The Saylor Academy, 2014.

[15] E.J. Naiburg and R.A. Maksimchuk, UML for Database Design, 1st ed., Boston, USA: Addison-Wesley, 2001.

[16] J. Rumbaugh, I. Jacobson, and G. Booch, The Unified Modeling Language Reference Manual, 1st ed., Essex, UK: Addison Wesley Longman, Inc., 1999. 